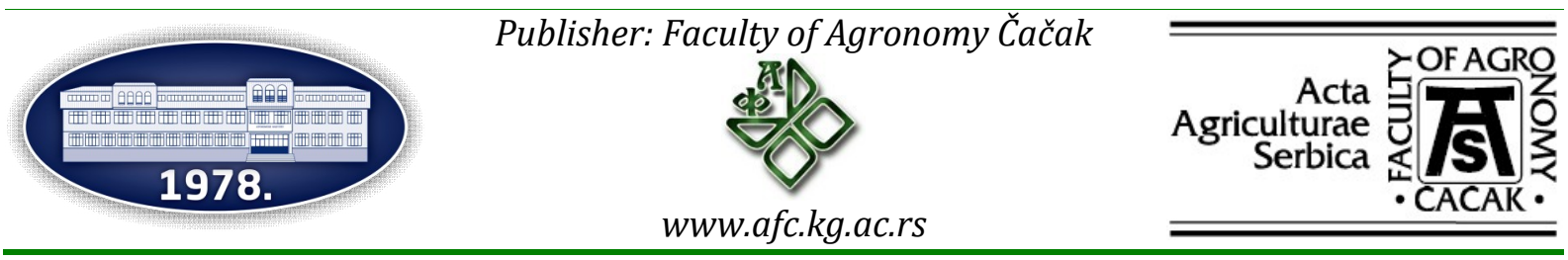

\title{
In vitro antioxidant activity of essential oil of aerial parts of Mentha pulegium $\mathrm{L}$.
}

\author{
Ahmed Hariri ${ }^{*}$, Naouel Ouis ${ }^{2}$, Djilali Bouhadi ${ }^{1}$, Zouaoui Benatouche ${ }^{1}$ \\ 1*Bioconversion Laboratory, Microbiology Engineering and Health Safety, University Mustapha STAMBOULI of Mascara \\ (UN 2901), BP. 763, Sidi Said, Mascara, 29000, Algeria. \\ ${ }^{2}$ Laboratory of Physical Chemistry of Macromolecules and Biological Interfaces, University Mustapha STAMBOULI of \\ Mascara (UN 2901), BP. 763, Sidi Said, Mascara, 29000, Algeria.
}

*Corresponding author: ahmed.hariri@univ-mascara.dz

Received 29 October 2020; Accepted 3 December 2020

\begin{abstract}
A B S T R A C T
This work was conducted to evaluate the antioxidant activity of the essential oil obtained from the aerial part of Mentha pulegium. The antioxidant power of the essential oil obtained by hydrodistillation using a Clevenger-type apparatus was evaluated by using three methods: free radical-scavenging activity, reducing power and liver lipid peroxidation assay. Results showed that Mentha pulegium oil displayed good quality according to its physicochemical characteristics, and a higher yield $5.1 \pm 0.2 \%$. The essential oil of Mentha pulegium showed a higher DPPH radical scavenging activity $90.54 \pm 1.5 \%$ at a concentration of $1000 \mu \mathrm{g} / \mathrm{mL}$. This value was close to the results obtained with ascorbic acid $96.23 \pm 1.2 \%$, and catechin $94.50 \pm 1.4 \%$. This oil exhibited significant potential for reducing iron (the value observed by optical density was $1.8 \pm 0.3$ ), while ascorbic acid and catechin provided an OD of $2.069 \pm 0.03$ and $2.66 \pm 0.016$ at the same concentration of $1000 \mu \mathrm{g} / \mathrm{mL}$. The tested oil protected against lipid peroxidation induced by $\mathrm{Fe}+2$, and considerably increased the percentage of anti lipid peroxidation in a dose-dependent manner. The studied oil displayed a good degree of antioxidant activity and can be exploited in food and pharmaceutical industries
\end{abstract}

Keywords: Antioxidant activity, DPPH, essential oil, lipid peroxidation, Mentha pulegium.

\section{И З В О Д}

Овај рад је спроведен за процену антиоксидативне активности есенцијалног уља добијеног из надземног дела биљке Mentha pulegium. Антиоксидативна снага есенцијалног уља добијеног хидродестилацијом помоћу апарата типа Clevenger процењена је применом три методе: активност уклањања слободних радикала, смањење снаге и тест пероксидације липида у јетри. Резултати су показали да је уље Mentha pulegium показало добар квалитет у складу са својим физичкохемијским карактеристикама и да је имало већи принос од 5,1 \pm 0,2\%. Есенцијално уље Mentha pulegium показало је већу активност уклањања $D P P H$ радикала $90,54 \pm 1,5 \%$ у концентрацији $1000 \mu \mathrm{g} / \mathrm{mL}$. Ова вредност била је близу резултата добијених са аскорбинском киселином $96,23 \pm 1,2 \%$ и катехином $94,50 \pm 1,4 \%$. Ово уље је имало значајан потенцијал за редукцију гвожђа, вредност уочена оптичком густином од $1,8 \pm 0,3$, док аскорбинска киселина и катехин дају $O D$ од 2,069 $\pm 0,03$ и $2,66 \pm 0,016$ у истој концентрацији $1000 \mu \mathrm{g} / \mathrm{mL}$. Тестирано уље штити од липидне пероксидације изазване $\mathrm{Fe}+2$ јонима, знатно повећава проценат анти-липидне пероксидације на начин који зависи од дозе. Испитивано уље је показало добар степен антиоксидативне активности и може се искористити у прехрамбеној и фармацеутској индустрији

Кључне речи: антиоксидативна активност, DPPH, есенцијална уља, липидна пероксидација, Mentha pulegiuт.

\section{Introduction}

Plants are a real source of natural and medicinal products once serving as the source of all drugs (Balandrin et al., 1993). Actually, the use of aromatic and medicinal plants in herbal medicine has been developed intensively by exploiting different herbs, fruits and legumes. Many studies were focused on naturally bioactive products that can preserve human health from oxidative stress damage caused by reactive oxygen species. The imbalance between reactive oxygen species and antioxidant defense system may lead to the chemical modification of biologically relevant macromolecules (DNA, carbohydrates, proteins or lipids). These patho-biochemical mechanisms cause the development of different diseases (Troszynska et al., 2002). Antioxidants are vital agents that possess the ability to protect the body from damage caused by free radical induced oxidative stress and retard the progress of several chronic diseases. Hence, the studies on natural antioxidants have gained increasingly greater importance. Many antioxidant substances naturally occurring in plant sources have been identified as potential free radical or active oxygen scavengers (Duh, 1998). Due to their richness in various bioactive compounds, plants have been used for food preservation, pharmaceutical treatment, alternative medicine and natural therapies (Lis-Balchin and Deans, 1997). It has long been acknowledged that some plant essential oils exhibit antioxidant activity and it is necessary to investigate those plants scientifically (Al-Bayati, 2008). Mentha 
pulegium L. belonging to the Labiatae family is one of the Mentha species commonly known as pennyroyal. This aromatic herb is native to Europe, North Africa, Minor Asia and the near East (Chalchat et al., 2000). The flowering aerial parts of Mentha pulegium have been traditionally used in food preparation and also as antimicrobials (Mahboubi and Haghi, 2008), in the treatment of cold, sinusitis, cholera, food poisonings, bronchitis and tuberculosis (Zargari, 1990). It is also used as antispasmodic, carminative, anti-inflammatory, diuretic, antitussive, antiflatulent and menstruation agent (Bouyahya et al., 2017a; Nickavar and Jabbareh, 2018). It is used as an aromatic stimulant, analgesic, and abortifacient (Gordon and Khojasteh, 2015), as an alternative pesticide and insect repellent (Cheraghi Niroumand et al., 2016; Domingues and Santos, 2019), as an antioxidant (El-Ghorab, 2006) and as a cytotoxic agent (Shirazi et al., 2004). The purpose of the present work was to determine the in vitro antioxidant activity of the essential oil extracted from the aerial part of Mentha pulegium.

\section{Material and Methods}

\section{Chemicals substances}

All chemicals and solvents were purchased from Sigma Aldrich (Munich, Germany), unless otherwise specified.

\section{Plant material}

The aerial parts of Mentha pulegium L. were collected during April 2018 in the region of Mascara (North-West of Algeria). The species was identified by botanists at SNV Faculty, University Mustapha STAMBOULI of Mascara. The collected plants were washed with tap water to remove all impurities and then with distilled water. The samples were dried in darkness at room temperature and chopped into small particles to increase the surface of diffusion.

\section{Isolation of essential oils}

A $100 \mathrm{~g}$ sample was submitted to hydro-distillation in $500 \mathrm{~mL}$ of distilled water for 3 hours, using a Clevenger-type apparatus (ST15 OSA, Staffordshire, UK) until total recovery of oil. The extracted essential oil was dried over anhydrous sodium sulfate. In order to preserve its original quality, the oil was stored at 4 ${ }^{\circ} \mathrm{C}$ until tested in an opaque glass bottle sealed to protect it from air and light (main agents of degradation). The essential oil yield was determined by the gravimetric method and expressed in terms of \% $\mathrm{w} / \mathrm{w}$ (ratio between the weight of the obtained oil and the weight of the sample to be treated). The purity of oil was assessed by measurement of physicochemical indices. The physical indices $\left(\mathrm{pH}\right.$, density at $20{ }^{\circ} \mathrm{C}$, relative density, refractive index at $20{ }^{\circ} \mathrm{C}$, rotatory power and miscibility with ethanol at 96\%) and chemical indices (acid, ester, carbonyl, saponification, peroxide and iodine number) were evaluated according to the European Pharmacopoeia (2000).

\section{Evaluation of the antioxidant activity}

$D P P H$ free radical-scavenging activity

The antioxidant activity of Mentha pulegium essential oil was evaluated in terms of hydrogen donating or radical-scavenging activity, using the stable free radical 2,2-diphenyl-1-picrylhydrazyl (DPPH) as a reagent. The ability of the oil to scavenge DPPH was determined by using the method described by Kirby and Schmidt (1997) with some modifications. The essential oil to be tested for its antioxidant potential was prepared in methanol to achieve the concentration of $1 \mathrm{mg} / \mathrm{mL}$. Dilutions were made to obtain concentrations of $500,250,125,62.5,31.25,15.62$, $7.81,3.90,1.99$, and $0.97 \mu \mathrm{g} / \mathrm{mL}$. A volume of $50 \mu \mathrm{L}$ of these solutions was added to $1950 \mu \mathrm{L}$ of methanol solution of DPPH (6.10-5 M) as a free radical source. The mixtures were stirred for 30 seconds and then incubated in the dark for $30 \mathrm{~min}$ at room temperature. The absorbance was measured using a UV/Vis spectrophotometer model Hitachi 4-2000 at $517 \mathrm{~nm}$ against pure methanol (Shimada et al., 1992). Ascorbic acid and catechin were used for comparison as positive controls. Lower absorbance of the reaction mixture indicated higher free radical-scavenging activity. The inhibition percentage of DPPH was calculated using the equation:

$\%$ of inhibition $=\left(\frac{\text { Absorbance of control }- \text { Absorbance of sample }}{\text { Absorbance of control }}\right) * 100$

Where: Absorbance of the control containing all reagents except the oil and absorbance of the sample (presence of the essential oil). IC50 value (concentration of substrate that inhibits $50 \%$ of the DPPH radicals present in the reaction medium) was determined from the $\%$ inhibition versus concentration plot, using a non-linear regression algorithm.

\section{Ferric-reducing power}

The ferric reducing power of essential oil was determined by using the potassium ferricyanide-ferric chloride method described by Yildirim et al. (2001). One $\mathrm{mL}$ of essential oil at different concentrations was mixed with $2.5 \mathrm{~mL}$ of $0.2 \mathrm{M}$ phosphate buffer $\mathrm{pH} 6.6$ and $2.5 \mathrm{~mL}$ of potassium ferricyanide solution $\mathrm{K} 3 \mathrm{Fe}(\mathrm{CN}) 6,1 \%$. After incubation for $20 \mathrm{~min}$ at $50{ }^{\circ} \mathrm{C}$, $2.5 \mathrm{~mL}$ of trichloroacetic acid $10 \%$ was added and the reaction mixture was centrifuged for $10 \mathrm{~min}$ at 3000 rpm (Sigma laborzentrifugen D-37620 Osterode am Harz, Germany). An aliquot of $2.5 \mathrm{~mL}$ of the supernatant from each mixture was mixed in a test tube with $2.5 \mathrm{~mL}$ of distilled water and $0.5 \mathrm{~mL}$ of ferric chloride solution $(0.1 \%)$ prepared freshly in distilled water. After $20 \mathrm{~min}$ of reaction time at $35{ }^{\circ} \mathrm{C}$, the absorbance was recorded at $700 \mathrm{~nm}$ against a blank that contained all reagents except the essential oil solutions and ferric chloride. The control was achieved by different concentrations of ascorbic acid and catechin. Higher absorbance of the reaction mixture indicated higher reducing power. Tests were carried out in triplicate. The concentration providing 0.5 of absorbance (IC50) was calculated by plotting absorbance at $700 \mathrm{~nm}$ against the corresponding sample concentration. 


\section{Liver Lipid peroxidation assay}

Lipid peroxidation assay in the liver tissues was evaluated using the thiobarbituric acid reactive substances (TBARS) method as described by Tatiya and Saluja (2010). The solution contained $0.5 \mathrm{~mL}$ of homogenate $10 \%, 1 \mathrm{~mL}$ of $\mathrm{KCl}(0.15 \mathrm{M})$ and $0.5 \mathrm{~mL}$ of different dilutions of essential oil. The lipid peroxidation was initiated by adding $100 \mu \mathrm{L}$ of ferric chloride $1 \mathrm{mM}$. After incubation for $30 \mathrm{~min}$ at $37^{\circ} \mathrm{C}$, the reaction mixture was stopped by addition of $2 \mathrm{~mL}$ of iced $\mathrm{HCl} 0.25 \mathrm{~N}$ containing 15\% TCA trichloroacetic acid (tissue homogenate was deproteinized by TAC), $0.38 \%$ thiobarbituric acid and $0.2 \mathrm{~mL}$ of Butylated Hydroxyl Toluene (BHT, $0.05 \%$ ). The mixture was heated for 60 min at $80^{\circ} \mathrm{C}$, cooled and centrifuged at $6900 \mathrm{rpm}$ for 15 $\min$. The absorbance of the supernatant was measured at $532 \mathrm{~nm}$ using a spectrophotometer against a blank containing all regents except the liver homogenate and essential oil. Identical experiments were carried out to determine the normal (without essential oil and $\mathrm{FeCl} 3$ ) and the level of lipid peroxidation in the tissues (with $\mathrm{FeCl} 3$ and without essential oil). For preparation of the homogenate, the liver was quickly removed after dissection of the rats, rinsed with physiological saline and homogenized at $4{ }^{\circ} \mathrm{C}$ in a solution of $0.15 \mathrm{M} \mathrm{KCl}$ by $10 \%$. The homogenate was centrifuged at $800 \mathrm{rpm}$ for 15 min to remove cellular debris; the supernatant was recovered to examine the in vitro lipid anti peroxidation (Singh et al., 2007). The percentage of anti-lipid peroxidation effect (\% ALP) was calculated by the following formula:

$$
\% A L P=\left(\frac{\text { A of FeCl3 }- \text { A of sample }}{\text { A of FeCl3 }- \text { A of normal }}\right) * 100
$$

\section{Data analysis}

All determinations were conducted in triplicates and results for each measured parameter were expressed as mean \pm SD. Data were statistically determined by the analysis of variance ANOVA at the significance level $(\mathrm{P}<0.05)$ using Microsoft Excel and SPSS statistics software 8.1.

\section{Results and discussion}

\section{Results of physic-chemical characterization}

The essential oil of the aerial part of Mentha pulegium presents a mobile liquid aspect, light yellow color and herbaceous minty odor. This oil was characterized by a higher yield $5.1 \pm 0.2 \%$. According to the literature, the essential oil yield of Mentha pulegium varies from $0.1 \%$ (Oliveira et al., 2011) to $5.4 \%$ (Bouyahya et al., 2017b). According to Marzouk et al. (2008), the plant polymorphism, seasonal, geographical variation and nutritional availability of plant affect extraction oil yields, which are higher when plants are extracted during the flowering period. Mentha pulegium showed greater yield compared with the cited research such as $1.45 \pm 0.01 \%$ reported by Abdelli et al. (2016) and $1.8 \%$ cited by Benabdallah et al. (2018). The physico-chemical analysis $(\mathrm{pH} 4.56 \pm 0.1$, density at $20{ }^{\circ} \mathrm{C} 0.86 \pm 0.01 \mathrm{~g} / \mathrm{mL}$, relative density $0.908 \pm 0.01 \mathrm{~g} / \mathrm{g}$, refractive index at $20{ }^{\circ} \mathrm{C} 1.486 \pm$
0.002 , rotatory power $+2.25 \pm 0.10$, miscibility with ethanol at $96 \% 1 / 10(\mathrm{v} / \mathrm{v})$, acid index $9.537 \pm 0.01 \mathrm{mg}$ $\mathrm{KOH} / \mathrm{g} \mathrm{EO}$, ester index $46.573 \pm 0.01 \mathrm{mg} \mathrm{KOH} / \mathrm{g}$ EO at $20{ }^{\circ} \mathrm{C}$, saponification index $56.11 \pm 0.01$, peroxide index $8.0 \pm 0.3$ meq. $02 / \mathrm{Kg}$ EO, carbonyl index $283.305 \pm$ 0.02 , and iodine number $1.5 \pm 0.1$ ) showed good quality of the studied oil.

\section{Results of antioxidant activity}

$D P P H$ free radical-scavenging activity

As shown in Fig. 1, the essential oil of aerial part of Mentha pulegium showed a higher DPPH radical scavenging activity $(90.54 \pm 1.5 \%)$ at a concentration of $1000 \mu \mathrm{g} / \mathrm{mL}$

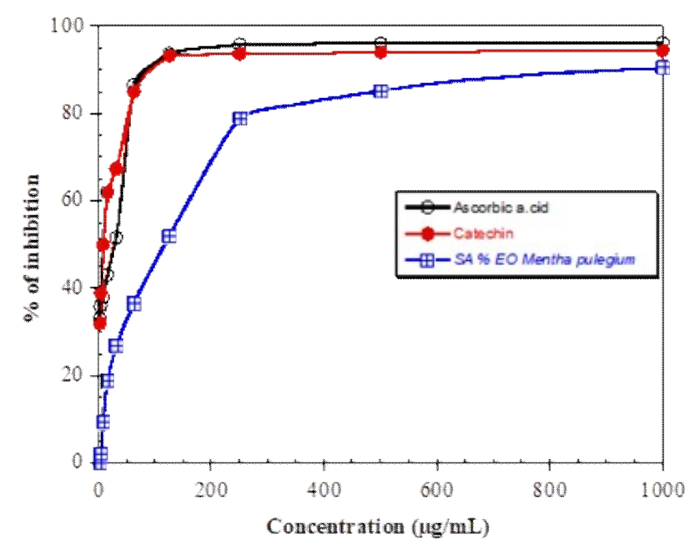

Figure 1. Free radical-scavenging activities of positive controls (ascorbic acid, catechin) and essential oil of Mentha pulegium measured by DPPH method. Values represent Mean $\pm \mathrm{SD} ; \mathrm{n}=3$; Confidence level $\mathrm{p} \leq 0.05$.

This result was close to the values found with ascorbic acid $96.23 \pm 1.2 \%$ and catechin $94.50 \pm 1.4 \%$. Result showed that the antioxidant activity of the essential oil was directly dependent on the concentrations used. According to Derwich et al. (2011), the antiradical activities of essential oils could be associated with their chemical composition, especially with their major compounds. The richness of Mentha pulegium essential oil in ketones, particularly pulegone, menthone, menthol (Ntalli et al., 2010), piperitone, and oxygenated monoterpenes (Pavela, 2008; Benomari et al., 2018), and neo-menthol (Abdelli et al., 2016), explains the antioxidant effect of this oil. The scavenger effect of active compounds on free radicals depends on the presence of free $\mathrm{OH}$ groups, in particular 3-OH, with a configuration 3',4'rthodihydroxy (Heim et al., 2002). The obtained results are in agreement with the findings of several authors who reported that the efficiency of an antioxidant to reduce DPPH essentially depends on its hydrogen donating ability, which is directly related to the presence of phenolic compounds (Hazzit et al., 2009) and the abundance of monoterpenes hydrocarbons (Ruberto and Baratta, 2000) and oxygenated monoterpenes (Tepe et al., 2004). The IC50 parameter commonly used to measure the antioxidant activity is necessary for each essential oil to reduce $50 \%$ of DPPH radical concentration in a defined period of time; a low IC50 value corresponds to a higher antioxidant activity. The positive controls catechin and ascorbic acid displayed lower values of IC50 $20 \pm 0.2$ and $32.5 \pm 0.5$ $\mu \mathrm{g} / \mathrm{mL}$, followed by the essential oil of Mentha pulegium $130 \pm 0.4 \mu \mathrm{g} / \mathrm{mL}$. The obtained IC50 of 
Mentha pulegium was lower than the value $69.60 \pm 1.72$ $\mathrm{mg} / \mathrm{mL}$ cited by Abdelli et al. (2016). According to the IC50 values, the antioxidant activity of the essential oil was lower than the antioxidant effect of catechin and ascorbic acid and higher than the value cited in the literature.

\section{Reducing power}

The reducing power assay is often used to estimate the ability of a natural antioxidant to donate an electron or hydrogen to form a more stable product (Shimada et al., 1992). The determination of the ferric reducing antioxidant was based on the reduction of $\mathrm{Fe}+3 /$ ferriccyanide complex to the ferrous form in the presence of antioxidants in the tested samples. The $\mathrm{Fe}+2$ were then monitored by measuring the formation of Perl's Prussian blue at $700 \mathrm{~nm}$. In fact, it is widely accepted that higher absorbance at $700 \mathrm{~nm}$ is correlated with reducing power (Shimada et al., 1992). This author reported that the reductive potential may be related to the presence of phenolic compounds, such as isothymol and carvacrol, due to the hydroxyl substitutions in the aromatic ring, which possess potent hydrogen-bonding abilities. The reducing capacity of the essential oil of Mentha pulegium increases in a concentrationdependent manner (Fig. 2).

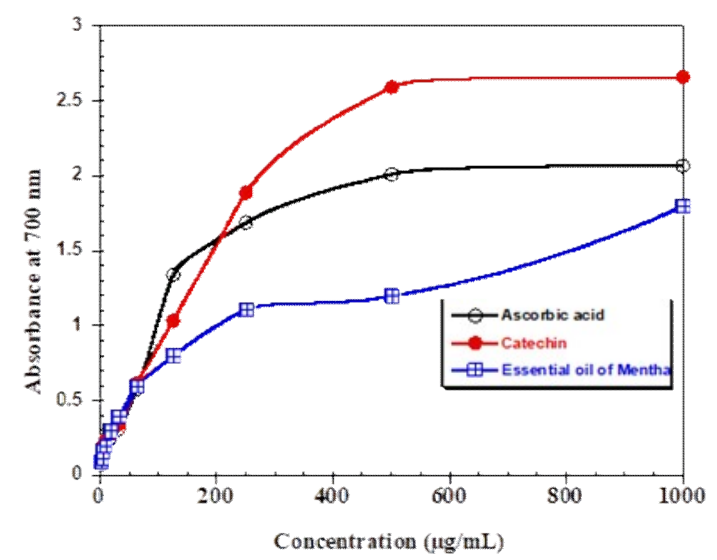

Figure 2. Antioxidant capacities of positive control (ascorbic acid, catechin) and essential oil of Mentha pulegium using ferric reducing power method. Values represent Mean \pm SD; $\mathrm{n}=3$; Confidence level $p \leq 0.05$.

We noted significant activity for reducing iron (the value observed by optical density was $1.8 \pm 0.3$ ), while ascorbic acid and catechin provided an OD of $2.069 \pm$ 0.03 and $2.66 \pm 0.016$ at the same concentration of $1000 \mu \mathrm{g} / \mathrm{mL}$. We can classify power reduction of iron as follows: catechin, ascorbic acid, and essential oil of Mentha pulegium. The positive controls (catechin and ascorbic acid) displayed lower values of IC50 $53 \pm 0.3$ and $58.3 \pm 0.4 \mu \mathrm{g} / \mathrm{mL}$, followed by the essential oil of Mentha pulegium $71.5 \pm 0.3 \mu \mathrm{g} / \mathrm{mL}$.

\section{Lipid peroxidation}

The inhibitory effect of the positive controls and essential oil of Mentha pulegium on Fe2+ induced lipid peroxidation in rat homogenates is shown in Fig. 3. The tested essential oil protected against lipid peroxidation induced by $\mathrm{Fe}+2$, considerably increased the percentage of anti lipid peroxidation in a dosedependent manner, and was close to those found by ascorbic acid and catechin with a percentage more than $76 \pm 2 \%$ and $73 \pm 1 \%$ at $1000 \mu \mathrm{g} / \mathrm{mL}$. This oil is effective in inhibiting the lipid peroxidation induced by the $\mathrm{Fe} 2+$ ascorbate system in rat homogenates. Lipid peroxidation is associated with a loss of membrane fluidity and an increase in membrane permeability, causing a decrease in physiological performance (Balu et al., 2005). The chemical structure of iron and its capacity to drive one electron reactions make iron a key factor in the formation of free radicals (Fraga and Oteiza, 2002). The generation of malondialdehyde (MDA) and related substances which react with thiobabiturique acid is inhibited by pulp oil (Tatiya and Saluja, 2010). This indicates significant activity of inhibiting the lipid peroxidation of oils. Phenolic substances are excellent nucleophiles and are able to scavenge radicals and inhibit lipid peroxidation, acting as breakers generated through lipid peroxidation. In addition, phenolic substances act as chelators of metal ions that induce oxidation (Han and Baik, 2008). The antioxidant capacity of essential oil may be associated with multiple systems, as they possess a chemical mixture with diverse functional groups, polarity and chemical behavior (Tepe et al., 2006).

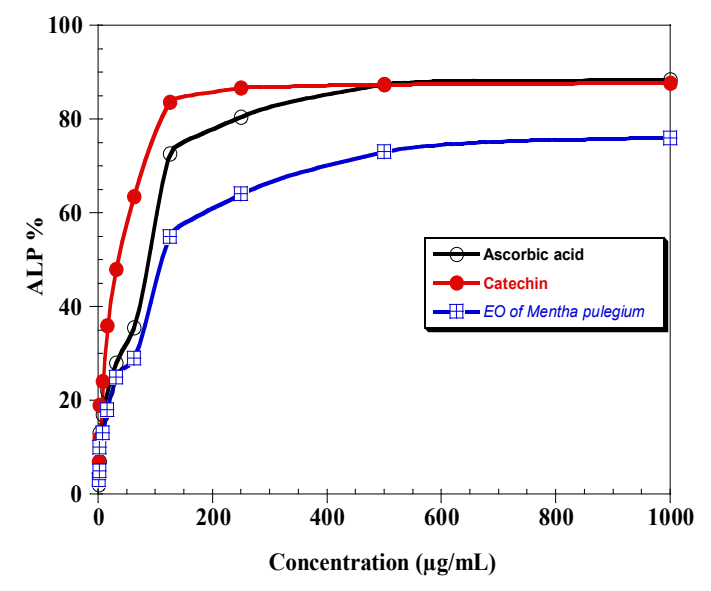

Figure 3. Antioxidant activity of positive control (ascorbic acid, catechin) and essential oils of Mentha pulegium. Values represent Mean $\pm S D ; n=3$; Confidence level $p \leq 0.05$.

\section{Conclusion}

This study indicated that the essential oil of the aerial part of Mentha pulegium showed greater yield, good quality and a higher DPPH radical scavenging activity (percentage of inhibition $90.54 \pm 1.5 \%$ ) at a concentration of $1000 \mu \mathrm{g} / \mathrm{mL}$. This result was close to the values found with ascorbic acid $96.23 \pm 1.2 \%$ and catechin $94.50 \pm 1.4 \%$. The studied oil showed a lower value of IC50 $130 \pm 0.4 \mu \mathrm{g} / \mathrm{mL}$. This oil displayed a significant activity for reducing iron (IC50 $71.5 \pm 0.3$ $\mu \mathrm{g} / \mathrm{mL}$ ) and was effective in inhibiting the lipid peroxidation induced by the $\mathrm{Fe} 2+$ ascorbate system in rat homogenate. It may provide a valuable source of natural antioxidants for commercial exploitation.

\section{References}

Abdelli, M., Moghrani, H., Aboun, A., Maachi, R. (2016). Algerian Mentha pulegium L. leaves essential oil: Chemical composition, antimicrobial, insecticidal and antioxidant activities. Industrial Crops and Products, 94, 197-205. 
Al-Bayati, F.A. (2008). Synergistic antibacterial activity between Thymus vulgaris and Pimpinella anisum essential oils and methanol extracts. Journal of Ethnopharmacology, 116, 403-406.

Balandrin, M., Kinghorn, A., Farnsworth, N. (1993). Plantderived natural products in drug discovery and development. In: Kinghorn, A.D., Balandrin, M.F. (Eds.), Human medicinal agents from plants. American chemical society, Washington, DC.

Balu, M., Sangeetha, P., Haripriya, D., Panneerselvam, C. (2005). Rejuvenation of antioxidant system in central nervous system of aged rats by grape seed extract. Neuroscience Letters, 383(3), 295-300.

Benabdallah, A., Boumendjel, M., Aissi, O., Rahmoune, C., Boussaid, M., Messaoud, C. (2018). Chemical composition, antioxidant activity and acetylcholinesterase inhibition of wild Mentha species from northeastern Algeria. South African Journal of Botany, 116, 131-139.

Benomari, F.Z., Andreu, V., Kotarba, J., Dib, M.E.A., Bertrand, C., Muselli, A., Costa, J., Djabou, N. (2018). Essential oils from Algerian species of Mentha as new bio-control agents against phytopathogen strains. Environmental Science and Pollution Research, 25(30), 29889-29900.

Bouyahya, A., Abrini, J., Et-Touys, A., Bakri, Y., Dakka, N. (2017a). Indigenous knowledge of the use of medicinal plants in the North-West of Morocco and their biological activities. European Journal of Integrative Medicine, 13, 9-25.

Bouyahya, A., Et-Touys, A., Bakri, Y., Talbaui, A., Fellah, H., Abrini, J., Dakka, N. (2017b). Chemical composition of Mentha pulegium and Rosmarinus officinalis essential oils and their antileishmanial, antibacterial and antioxidant activities. Microbial Pathogenesis, 111, 41-49.

Chalchat, J.C., Gorunovic, M.S., Maksimovic, Z.A, Petrovic, S.D. (2000). Essential oil of wild growing Mentha pulegium L. from Yugoslavia. Journal of Essential Oil Research, 12(5), 598-600.

Cheraghi Niroumand, M, Farzaei, M.H., Karimpour Razkenari, E., Amin, G., Khanavi, M., Akbarzadeh, T., Shams-Ardekani, M.R. (2016). An evidence-based review on medicinal plants used as insecticide and insect repellent in traditional Iranian medicine. Iranian Red Crescent Medical Journal, 18(2), e22361.

Derwich, E., Benziane, Z., Boukir, A. (2011). Antibacterial activity and chemical composition of the leaf essential oil Mentha rotundifolia from Morocco. Electronic Journal of Environmental, Agricultural and Food Chemistry, 9, 19-28.

Domingues, P.M., Santos, L. (2019). Essential oil of pennyroyal (Mentha pulegium): Composition and applications as alternative to pesticides - New tendencies. Industrial Crops and Products, 139(111534), 1-20.

Duh, P.D. (1998). Antioxidant activity of burdock (Arctium lappa Linne): its scavenging effect on free radical and active oxygen. Journal of the American Oil Chemists Society, 75 (4), 455-461.

El-Ghorab, A.H. (2006). The chemical composition of Mentha pulegium L. essential oil from Egypt and its antioxidant activity. Journal of Essential Oil Bearing Plants, 9(2), 183 195.

European Pharmacopoeia, 2000. Dritter Nachtrag, 3rd ed. Council of Europe, Strasbourg, pp. 499-500.

Fraga, C.G, Oteiza, P.I. (2002). Iron toxicity and antioxidant nutrients. Toxicology, 180(1), 23-32.

Gordon, P., Khojasteh, S.C. (2015). A decades-long investigation of acute metabolism based hepatotoxicity by herbal constituents: a case study of pennyroyal oil. Drug Metabolism Reviews, 47, 12-20.

Han, H., Baik, B.K. (2008). Antioxidant activity and phenolic content of lentils (Lens culinaris), chickpeas (Cicer arietinum L.), peas (Pisum sativum L.) and soybeans (Glycin max), and their quantitative changes during processing. International Journal of Food Sciences and Technology, 43(11), 1971-1978.

Hazzit, M., Baaliouamer, A., Verissimo, A.R., Faleiro, M.L., Miguel, M.G. (2009). Chemical composition and biological activities of Algerian Thymus oils. Food Chemistry, 116 (3), 714-721.

Heim, K.E., Tagliaferro, A.R., Bobilya, D.J. (2002). Flavonoid antioxidants: chemistry, metabolism and structureactivity relationships. Journal of Nutritional Biochemistry, 13(10), 572-584.

Kirby, A.J., Schmidt, R.J. (1997). The antioxidant activity of Chinese herbs for eczema and of placebo herbs. Journal of Ethnopharmacology, 56 (2), 103-108.

Lis-Balchin, L., Deans, S.G. (1997). Bioactivity of selected plant essential oils against Listeria monocytogenes. Journal of Applied Bacteriology, 82(6), 759-762.

Mahboubi, M., Haghi, G. (2008). Antimicrobial activity and chemical composition of Mentha pulegium L. essential oil. Journal of Ethnopharmacology, 119(2), 325-327.

Marzouk, B., Fredj, M.B.H., Chraif, I., Mastouri, M., Boukef, K., Marzoul, Z. (2008). Chemical composition and antimicrobial activity of essential oils from Tunisian Mentha pulegium L. Journal of Food Agriculture and Environment, 6, 78-82.

Nickavar, B., Jabbareh, F. (2018). Analysis of the essential oil from Mentha pulegium and identification of its antioxidant constituents. Journal of Essential Oil Bearing Plants, 21, 223-229.

Ntalli, N.G., Ferrari, F., Giannakou, I., Menkissoglu-Spiroudi, U. (2010). Phytochemistry and nematicidal activity of the essential oils from 8 Greek Lamiaceae aromatic plants and 13 terpene components. Journal of Agricultural and Food Chemistry, 58(13), 7856-7863.

Oliveira, R.A., Sa, I.C.G., Duarte, L.P., Oliveira, F.F. (2011). Constituents volatiles' de Mentha pulegium L. E. Plectranthus amboinicus (Lour.) Spreng. Revista Brasileira de Plantas Medicinais, 13(2), 165-169.

Pavela, R. (2008). Insecticidal properties of several essential oils on the house fly (Musca domestica L.). Phytotherapy Research, 22(2), 274-278.

Ruberto, G., Baratta, M.T. (2000). Antioxidant activity of selected essential oils components in two lipid model systems. Food Chemistry, 69(2), 167-174.

Shimada, K., Fujikawa, K., Yahara, K., Nakamura, T. (1992). Antioxidative properties of xanthan on the autoxidation of soybean oil in cyclodextrin emulsion. Journal of Agricultural and Food Chemistry, 40(6), 945-948.

Shirazi, F., Ahmadi, N., Kamalinejad, M. (2004). Evaluation of Northern Iran Mentha pulegium L. Cytotoxicity Daru, 12(3), 106-110.

Singh, R., Singh, S., Kumar, S., Arora, S. (2007). Free radical scavenging activity of acetone extract/fractions of Acacia auriculiformis. Food Chemistry, 103, 1403-1410.

Tatiya, A.U., Saluja, A.K. (2010). Evaluation of phytochemical standards and in vitro antioxidant activity of tannins rich fraction of stem bark of Bridelia retusa. International Journal of PharmTech Research, 2(1), 649-655.

Tepe, B., Daferera, D., Sokmen, M., Polissiou, M., Sokmen, A. (2004). The in vitro antioxidant and antimicrobial activities of the essential oil and various extracts of Origanum syriacum L. var. bevanii. Journal of the Science of Food and Agriculture, 84(11), 1389-1396.

Tepe, B., Sokem, M., Akpulat, H.A., Yumrutas, O., Sokmen, A. (2006). Screening of antioxidative properties of the methanolic extract of Pelargonium endlicherianum Fenzyl., Verbascum wiedemannianum Fisch. \& Mey., Sideritis libanotica Labill. Subsp. linearis (Bentham) Borm., Centaurea mucronifera DC. and Hieracium cappadocicum Freyn from Turkish flora. Food Chemistry, 98, 9-13.

Troszynska, A., Estrella, I., Luisa Lopez-Amores, M., Hernandez, T. (2002). Antioxidant activity of pea (Pisum sativum L.) seed coat aceton extract. LWT-Food Sciences and Technology, 35(2), 158-164.

Yildirim, A., Mavi, A., Kara, A.A. (2001). Determination of antioxidant and antimicrobial activities of Rumex crispus L. extracts. Journal of Agricultural and Food Chemistry, 49(8), 4083-4089.

Zargari, A. (1990). Herbal Medicines. Publication of Tehran University, Tehran. 